\title{
Spatial analysis of the regional variation of reproductive tract infections and spousal migration correlates in Nepal
}

\author{
Derek C. Johnson, ${ }^{1}$ Pema Lhaki, ${ }^{2}$ Charlotte Buehler Cherry, ${ }^{3}$ Mirjam-Colette Kempf, ${ }^{4,5}$ \\ Eric Chamot, ${ }^{1}$ Sten H. Vermund, ${ }^{6,7}$ Sadeep Shrestha ${ }^{1}$ \\ ${ }^{1}$ Department of Epidemiology, University of Alabama at Birmingham, Birmingham, AL, USA; \\ ${ }^{2}$ Nepal Fertility Care Center International, Kathmandu, Nepal; ${ }^{3}$ Vanderbilt Institute for Global Health, \\ Vanderbilt University School of Medicine, Nashville, TN; ${ }^{4}$ School of Nursing, University of Alabama at \\ Birmingham, Birmingham, AL; ${ }^{5}$ Department of Health Behavior, University of Alabama at Birmingham, \\ AL; ${ }^{6}$ Department of Pediatrics, Vanderbilt University School of Medicine, Nashville, TN; ${ }^{7}$ Yale School of \\ Public Health, New Haven, CT, USA
}

\section{Abstract \\ Nepal has a diverse geographic landscape that could potential- ly create clustered subpopulations with regional socio-cultures}

\footnotetext{
Correspondence: Sadeep Shrestha, Department of Epidemiology, University of Alabama at Birmingham, 1665 University Boulevard, 35294-0022 Birmingham, AL, USA.

E-mail: sshrestha@uab.edu
}

Key words: Reproductive tract infection; Sexually transmitted infection; Migration; Demography; Nepal.

Acknowledgements: we would like to thank the staff at Nepal Fertility Care Center who helped utilise the NDHS. We would also like to thank the University of Alabama at Birmingham's Comprehensive Cancer Center for supporting DJ through a National Institutes of Health Cancer Prevention and Control Training Grant (R25CA47888).

Conflict of interest: the authors declare no potential conflict of interest.

Contributions: DCJ contributed to acquiring the data, study design, data analysis, and manuscript preparation; PL contributed to acquiring the data and helped draft the manuscript; $\mathrm{CBC}$ provided technical assistance with GIS mapping and helped write the manuscript; M-CK contributed to data analysis and provided assistance in designing the research question; EC provided assistance in developing the research question and helped edit the manuscript; SHV provided advice on data analysis and contributed to drafting the discussion; SS was the principal investigator of the study and helped in acquiring the data and in manuscript preparation.

Received for publication: 26 September 2016.

Revision received: 3 April 2017.

Accepted for publication: 15 April 2017

CC Copyright D.C. Johnson et al., 2017

Licensee PAGEPress, Italy

Geospatial Health 2017; 12:513

doi:10.4081/gh.2017.513

This article is distributed under the terms of the Creative Commons Attribution Noncommercial License (CC BY-NC 4.0) which permits any noncommercial use, distribution, and reproduction in any medium, provided the original author(s) and source are credited. that could result in differential health outcomes. With an alarming rise in married male populations migrating for work, it is possible that these migrants are engaged in risky sexual behaviour, putting their wives at risk for infectious disease outcomes, including reproductive tract infections (RTI), when they return home. The prevalence of male migration varies by geographic region in Nepal and this variation could potentially contribute to different RTI rates. Using a cross-sectional dataset (the 2011 Nepal Demographic and Health Survey) including 9607 married women, we investigated geospatial and socio-cultural factors associated with the symptoms of RTIs with a focus on the husbands' migration status. Choropleth maps were created to illustrate areas with high percentages of RTIs that correlated with migration patterns. Overall, $31.9 \%$ of the husbands were migrating for work. After adjusting for wealth, contraception use, age at first marriage, urban/rural status and husband's education, women whose husbands had been absent for a year or more in Nepal's Mid-West region (OR 1.93 95\%, CI 1.02-3.67) or Far-West region (OR 2.89 $95 \%$, CI 1.24-6.73) were more likely to report RTI-like symptoms than others. Our results suggest a potential association between husbands' migration status and Nepali women reporting RTI symptoms by geographic regions. However, further research is needed to put this outcome on a stronger footing with respect to this under-studied population, specifically in the context of geographical variation.

\section{Introduction}

With a quarter of Nepal's 29 million citizens living below the poverty line (Asian Development Bank, 2016), Nepal is facing health and socioeconomic disparities which have compelled millions of Nepalese to look for work away from home. Currently, over 2.2 million Nepalese, mostly men, are engaged in migrant work (Central Bureau of Statistics, 2012a, 2012b). These workers annually send approximately 3 billion dollars in remittance to their country, comprising 15\% of Nepal's GDP (Government of Nepal, 2014). Due to the large number of Nepali men spending extended periods of time working away from home, it is possible that Nepal's large pool of male migrant workers is engaged in risky sexual behaviour, putting their wives at risk for reproductive tract infections (RTIs) when they return home.

According to World Health Organization (WHO) female RTIs 
can be endogenous, iatrogenic or sexually transmitted (WHO, 2005). They are often asymptomatic and represent a significant cause of maternal morbidity and mortality in low and middleincome countries (LMIC). According to the Nepalese Ministry of Health and Population (MOHP) and based on previous studies conducted in Nepal RTIs are prevalent but not equally distributed across different geographic regions (MOHP, 2012). Studies have suggested that physical and social differences between local environment conditions, such as lack of access to clean water or high prevalence of squatter settlements can cause an increase in RTI rates (Hernandez et al., 2006). A cross sectional study of 282 women in seven randomly chosen health centres in Nepal's Kaski District found that $78.9 \%$ of women had at least two symptoms of RTIs (WHO, 2011). A study of 104 women from the outpatient department of gynaecology at Tribhuvan University Teaching Hospital in Nepal's capital, Kathmandu, found that $30 \%$ of women reported RTI symptoms (Bohara et al., 2012). Women surveyed during a gynaecological camp conducted in Bajhang District in the Far-West Development Region (DR), found that $13.9 \%$ of the 530 women surveyed had an RTI (Tuladhar, 2005). Among women attending a reproductive health camp in the ethnically homogenous municipality of Khokana, 23.5\% had clinical cervicitis (Johnson et al., 2013). Given geographic variations in RTI prevalence, understanding how geospatial and sociocultural factors are related to RTIs can help anticipate priorities in the health of Nepali migrant workers and among their wives or other sexual partners.

Nepal has a diverse geographic landscape that could potentially result in the creation of clustered subpopulations at high risk for RTIs. Nepal is divided into five DRs (Eastern, Central, Western, Mid-West, and Far-West) and three ecological zones (Mountain, Hill and Terai). The two former regions represent over $77 \%$ of Nepal's land mass and $52 \%$ of its population. In contrast, the Terai region (consisting of tropical grasslands, savannahs, forests and river valleys in the South) represents $23 \%$ of Nepal's land mass and $48 \%$ of its population (Central Bureau of Statistics, 2012a, 2012b). Approximately 19\% of Nepal's population lives in urban areas where $40 \%$ of urban adolescents have comprehensive knowledge of sexually transmitted infections (STIs) (Khanal et al., 2013), but in the rural areas of Nepal only one-third of young men and one-fourth of young women have any substantial knowledge of STIs (Khatiwada et al., 2013). Residents of Nepal's Terai ecological region report some of the lowest rates of condom use in Nepal (Central Bureau of Statistics, 2012a, 2012b).

The prevalence of male migration in Nepal varies by region and this variation could potentially contribute to geographically different RTI rates. A majority of migrant workers who travel to India for employment come from Nepal's western DRs. However, out of the Nepali migrant workers registered for labour permits in countries other than India, 64\% come from the two non-western DRs (Eastern DR, Central DR) (Government of Nepal, 2014). Fifty-seven percent of households report at least one member leaving home for work within the last five years, even higher $(66 \%)$ in the Far-West DR (Central Bureau of Statistics, 2012a, 2012b). Knowing that RTI rates vary by region, the uneven regional distribution of migration patterns in Nepal is potentially a RTI risk factor. RTIs include STIs (Kim le et al., 2012) and previous research has shown that men who engage in migrant work are at higher risk for STIs, transmissible to their wives when they return home (7.8). Migrant workers represent $<10 \%$ of Nepal's population but $41 \%$ of the reported human immunodeficiency virus (HIV) infections (Bam et al., 2013). A study of male migrant workers in the Nepali district of Doti reported that $8 \%$ of returning migrant workers was infected with the human immunodeficiency virus (HIV) and $22 \%$ were infected with syphilis (Poudel et al., 2003). Circular migration, where individuals leave their partners for work and return only periodically, is one of the most common forms of migrant work in Nepal and it is correlated with an increased STI risk (Zuma et al., 2005). Complicating the migration-STI association, migratory men sometimes establish parallel sexual partnerships at their distant workplaces, forming long-term bridges that facilitate the spread of STIs (Nguyen et al., 2011).

Geospatial and sociocultural factors might be associated with the sexual health of Nepali migrant worker's spouses. The objective of our exploratory study was to investigate the geospatial differences between the prevalence of RTI symptoms reported by married Nepali women enrolled in the 2011 Nepal Demographic and Health Survey (NDHS) and assess the impact of their husbands' migration status.

\section{Materials and Methods}

\section{Demographic and health survey data}

The NDHS programme was established in Nepal by the United States Agency for International Development (USAID) in 1984 (USAID, 2006). The goal was to provide decision makers and government officials with improved information and analyses useful for making health policy choices on marriage, fertility, family planning, reproductive health, child health, and HIV/AIDS. The standard version of the programme is conducted every five years and began in 1996. However, an in-depth assessment of fertility and family planning in Nepal was conducted already in 1987.

The 2011 NDHS programme included 12,674 women of reproductive age (15-45), but our study sample was restricted to all 9607 married women in the NDHS. Data for the 2011 NDHS are based on a two-stage random sample design. During the first stage of sampling, a stratified sample of enumeration areas (EA) is selected with a probability of selection proportional to their size. An EA can be a city block or an apartment building in urban areas, while in rural areas it is typically a village or group of villages. The population and size of sampled clusters vary, but on average, clusters contain 100 to 300 households, 20 to 30 of which are randomly selected for survey participation. During the second stage of sampling, a number of households are selected for surveying by equal probability systematic sampling in the EAs. In our study, a household questionnaire was completed for each selected household to identify women of age 15-49, men of age 15-59 (15-54 or 15-49 in some surveys) and children under the age of five. Every eligible woman was interviewed with an individual questionnaire (USAID, 2012).

\section{Nepal Demographic and Health Survey geographic information systems data}

The NDHS has been collecting spatial and demographic data since 2001 in Nepal; detailed methodology is described elsewhere (Burgert et al., 2013). Briefly, coordinate locations (latitude and longitude) represent the population centre of a sampling cluster. Cluster coordinates are linked to geographic information system (GIS) administrative unit shape files. Latitude and longitude positions of all clusters contain random errors according to the follow- 
ing criteria by the NDHS to maintain respondent privacy: i) urban clusters contain between 0 and $2 \mathrm{~km}$ of error; ii) rural clusters contain 0 and $10 \mathrm{~km}$ of error. The error, however, is restricted so that clusters stay within the country and within the NDHS survey region where the surveys were conducted (Burgert et al., 2013).

GIS data for the 2011 NDHS are represented at three levels: i) Nepal's five DRs; ii) Nepal's three ecological zones; and iii) a subregional level containing 13 combinations of the development and ecological zone (Central Hill, Central Mountain, Central Terai, Eastern Hill, Eastern Mountain, Eastern Terai, Far-Western Hill, Far-Western Terai, Far/Mid/Western Mountain, Mid-Western Hill, Mid-Western Terai, Western Hill, Western Terai) (Burgert et al., 2013).

\section{Reproductive tract infections outcome, migration status and variables of interest}

A woman is considered to have a RTI symptom if she answered yes to either of the following NDHS questions: Had abnormal genital discharge in last 12 months or Had a genital sore or ulcer in last 12 months (Khatiwada et al., 2013). This study used the definition of male migration found in the NDHS report Impact of Male Migration on Contraceptive Use, Unmet Need, and Fertility in Nepal (Khanal et al., 2013). The report defines male migration as a non-resident husband who has migrated internationally or within the country. This definition does not specify the length of migration time, nor does it differentiate between reasons for migration. However, given the high rate of male labour migration in Nepal, the report assumes the vast majority of non-resident husbands are away for work. The NDHS survey question Is your husband/partner living with you now or is he staying elsewhere? is asked to assess male migration. If a woman states that her husband/partner is living elsewhere, then the amount of time her husband/partner is away from home is determined by a follow-up question For how long have you and your husband not been living together? We categorised this time as either $\leq 1$ year or alternatively as away $>1$ year in order to follow the categorisation of migrant time used in the standard national reports conducted using the NDHS data (Khanal et al., 2013).

Other covariates were classified as demographic, socioeconomic status (SES), sexual behavioural or geographic variables. Demographic variables included age (used as a continuous or a categorical variable for descriptive tables) and urban/rural residence. SES variables included an asset index based wealth (categorised as lowest, low, middle, high, highest) and the educational level (no education, primary, secondary or higher education) for each gender. Sexual behaviour variables included questions such as contraception currently used (condom, other or none); ever heard of a STI; and age at first marriage. The geographic variables included the five DRs, the three ecological zones, the 13 development and ecological zone combinations (Central Hill, Central Mountain, Central Terai, Eastern Hill, Eastern Mountain, Eastern Terai, Far-Western Hill, Far-Western Terai, Far/Mid/Western Mountain, Mid-Western Hill, Mid-Western Terai, Western Hill, Western Terai) as well as urban/rural residence.

\section{Ethical considerations}

The Institutional Review Board at the University of Alabama at Birmingham and Ethics Review Board at the Nepal Health Research Council approved this study.
Table 1. Married women with reproductive tract infections by descriptive characteristics according to the 2011 Nepal Demographic and Health Survey. Reported RII symptom (\%)

Time of migration Migrating $>1$ year $(\mathrm{n}=540)$ Migrating $\leq 1 \quad(\mathrm{n}=2337)$ Not currently migrating $(\mathrm{n}=6575)$

Age of migrating husband (years) 15 to $25(n=2826)$ $>25$ to $35(\mathrm{n}=3536)$ $>35(\mathrm{n}=3086)$

Asset-based wealth index Lowest $(\mathrm{n}=1920)$

Low $(n=1755)$

Middle $(\mathrm{n}=1765)$

High $(\mathrm{n}=1860)$

Highest $(\mathrm{n}=2152)$

Contraception currently used Condoms $(\mathrm{n}=487)$

Other $(\mathrm{n}=4667)$

None $(\mathrm{n}=4298)$

Woman's education level

No education $(\mathrm{n}=4439)$

Primary $(n=1790)$

Secondary $(\mathrm{n}=2620)$

Higher $(n=602)$

12.9

12.3

14.9

Husband's education level

No education $(\mathrm{n}=1723)$

Primary $(\mathrm{n}=2245)$

Secondary $(\mathrm{n}=4163)$

Higher $(\mathrm{n}=1277)$

Ever heard of STI

Yes $(n=8447)$

No $(\mathrm{n}=1005)$

Urban/rural residence

Urban $(\mathrm{n}=2581)$

Rural $(\mathrm{n}=6871)$

Development region

Eastern $(n=2212)$

Central $(\mathrm{n}=2232)$

Western $(\mathrm{n}=1721)$

Mid-Western $(\mathrm{n}=1754)$

Far-Western $(\mathrm{n}=1539)$

DHS sub-zone

Eastern Mountain $(\mathrm{n}=537)$

Central Mountain $(\mathrm{n}=485)$

Western Mountain $(\mathrm{n}=534)$

Eastern Hill $(\mathrm{n}=759)$

Central Hill $(\mathrm{n}=789)$

Western Hill $(\mathrm{n}=838)$

Mid-Western Hill $(\mathrm{n}=684)$

Far-Western Hill $(\mathrm{n}=602)$

Eastern Terai $(\mathrm{n}=914)$

Central Terai $(\mathrm{n}=953)$

Western Terai $(\mathrm{n}=880)$

Mid-Western Terai $(\mathrm{n}=795)$

Far-Western Terai $(\mathrm{n}=678)$

RTI, reproductive tract infections; STI, sexually transmitted infection; DHS, Demographic and Health Survey. *P value for univarate analysis within the 2011 Nepal Demographic and Health Survey. 


\section{Statistical analysis}

We described the frequencies of potential risk factors for women with and without RTI symptoms, using analysis of variance and Chi-square statistical tests. Multivariable logistic regression models stratified by DR investigated the association of the husband's migration status and reporting RTI symptoms while adjusting for asset-based wealth index, contraception use, age at first marriage, urban/rural status, and husband's education. All variables included in the multivariable models were selected based on: i) a review of the RTI risk factor literature from developing countries or ii) a $\mathrm{P}$ value of $<0.1$ in univariate analyses.

Due to the complex survey design of the NDHS, specific statistical procedures were used to correctly estimate variance. Variance estimation for univariate and multivariate statistical methods contained in the SAS PROC SURVEY procedures in SAS version 9.4 (SAS Institute, Cary, NC, USA) were used to perform all statistical analyses and account for the NDHS survey design.

ArcGIS version 10.1 (ESRI, Redlands, CA, USA) was used to produce choropleth maps of the percentage and change in percentage of women reporting RTI symptoms according to a husband's migration status.

\section{Results}

The average age of women surveyed was $31.3(\mathrm{SD} \pm 0.13)$ years. Almost one third of married women reported that their husbands were currently migrating for work, (not currently migrating, $67.9 \%$, migrating for $\leq 1$ year, $25.7 \%,>1$ year, $6.3 \%$ ). Of the women whose husbands were migrating for work, $12.4 \%$ of them reported RTI symptoms, while $14.9 \%$ of women whose husbands were not migrating for work reported RTI symptoms $(\mathrm{P}=0.35)$. Of the $12.6 \%$ of women who answered yes to at least one question about RTI symptoms, $19.9 \%$ said they had a genital sore or ulcer and $92.7 \%$ a genital discharge in the last 12 months.

Univariate analysis of these married women indicated that the

Table 2. Descriptive characteristics of women in the 2011 Nepal Demographic and Health Survey by development region.

\begin{tabular}{|c|c|c|c|c|c|c|}
\hline & astern $(\mathrm{n}=221$ & ntral $(\mathrm{n}=223$ & $\begin{array}{l}\text { velopment reg } \\
\text { estern }(n=172\end{array}$ & Western (n= & Far-Western & P* \\
\hline $\begin{array}{l}\text { Husband's migration, } n(\%) \\
\text { Migrating }>1 \text { year } \\
\text { Migrating } \leq 1 \text { year } \\
\text { Not currently migrating }\end{array}$ & $\begin{array}{c}191(8.6) \\
471(21.3) \\
1550(70.1)\end{array}$ & $\begin{array}{c}114(5.1) \\
471(21.1) \\
1647(73.8)\end{array}$ & $\begin{array}{c}135(7.8) \\
504(29.3) \\
1082(62.9)\end{array}$ & $\begin{array}{c}59(3.4) \\
422(24.0) \\
1274(72.6)\end{array}$ & $\begin{array}{c}42(2.7) \\
471(30.6) \\
1026(66.7)\end{array}$ & 0.001 \\
\hline $\begin{array}{l}\text { RTI symptoms } \\
\text { Yes } \\
\text { No }\end{array}$ & $\begin{array}{c}293(13.2) \\
1918(86.8)\end{array}$ & $\begin{array}{c}287(12.9) \\
1941(87.1)\end{array}$ & $\begin{array}{c}221(12.9) \\
1499(87.1)\end{array}$ & $\begin{array}{c}254(14.5) \\
1500(85.5)\end{array}$ & $\begin{array}{c}144(9.4) \\
1395(90.6)\end{array}$ & 0.06 \\
\hline $\begin{array}{l}\text { Age (years) } \\
\text { Mean (SD) } \\
\text { Median (IQR) }\end{array}$ & $\begin{array}{c}31.3(0.2) \\
29.9(23.9-37.5)\end{array}$ & $\begin{array}{c}31.5(0.3) \\
30.6(23.7-38.2)\end{array}$ & $\begin{array}{c}31.8(0.3) \\
30.7(23.9-38.2)\end{array}$ & $\begin{array}{c}30.1(0.2) \\
28.7(22.6-36.3)\end{array}$ & $\begin{array}{c}30.7(0.2) \\
28.9(23.2-36.7)\end{array}$ & 0.41 \\
\hline $\begin{array}{l}\text { Age at first marriage } \\
\text { Mean (SD) } \\
\text { Median (IQR) }\end{array}$ & $\begin{array}{c}18.2(0.2) \\
17.3(15.1-19.9)\end{array}$ & $\begin{array}{c}17.1(0.2) \\
15.9(14.3-18.4)\end{array}$ & $\begin{array}{c}17.4(01) \\
16.6(14.8-18.6)\end{array}$ & $\begin{array}{c}16.8(0.1) \\
15.9(14.4-17.8)\end{array}$ & $\begin{array}{c}16.5(0.1) \\
15.8(14.2-17.5)\end{array}$ & 0.63 \\
\hline $\begin{array}{l}\text { Asset-based wealth quintiles, } n \text { (\%) } \\
\text { Lowest } \\
\text { Low } \\
\text { Middle } \\
\text { High } \\
\text { Highest }\end{array}$ & $\begin{array}{l}395(17.9) \\
430(19.4) \\
462(20.9) \\
488(22.0) \\
437(19.8)\end{array}$ & $\begin{array}{l}258(11.5) \\
432(19.4) \\
433(19.4) \\
439(19.7) \\
670(30.0)\end{array}$ & $\begin{array}{l}140(8.1) \\
242(14.1) \\
305(17.7) \\
447(26.0) \\
587(34.1)\end{array}$ & $\begin{array}{l}619(35.3) \\
342(19.5) \\
301(17.1) \\
247(14.1) \\
246(14.0)\end{array}$ & $\begin{array}{l}510(33.1) \\
310(20.1) \\
266(17.3) \\
241(15.7) \\
212(13.8)\end{array}$ & 0.001 \\
\hline $\begin{array}{l}\text { Contraception currently used, } \mathrm{n} \text { (\%) } \\
\text { Condom } \\
\text { Other } \\
\text { None }\end{array}$ & $\begin{array}{l}79(3.6) \\
963(43.5) \\
1170(52.9)\end{array}$ & $\begin{array}{c}105(4.7) \\
1174(52.6) \\
953(42.7)\end{array}$ & $\begin{array}{c}84(4.9) \\
754(43.8) \\
883(51.3)\end{array}$ & $\begin{array}{l}101(5.8) \\
742(42.2) \\
912(52.0)\end{array}$ & $\begin{array}{l}118(7.7) \\
667(43.3) \\
754(49.0)\end{array}$ & 0.001 \\
\hline $\begin{array}{l}\text { Woman's education level, n (\%) } \\
\text { No education } \\
\text { Primary } \\
\text { Secondary } \\
\text { Higher }\end{array}$ & $\begin{array}{l}812(36.7) \\
494(22.3) \\
783(35.4) \\
122(5.6)\end{array}$ & $\begin{array}{l}1140(51.1) \\
397(17.8) \\
501(22.4) \\
194(8.7)\end{array}$ & $\begin{array}{l}602(35.0) \\
350(20.3) \\
646(37.5) \\
123(7.2)\end{array}$ & $\begin{array}{c}987(56.2) \\
313(17.8) \\
370(21.1) \\
85(4.9)\end{array}$ & $\begin{array}{c}904(58.7) \\
237(15.4) \\
320(20.8) \\
78(5.1)\end{array}$ & 0.001 \\
\hline $\begin{array}{l}\text { Husband's education level, n (\%) } \\
\text { No education } \\
\text { Primary } \\
\text { Secondary } \\
\text { Higher }\end{array}$ & $\begin{array}{c}315(14.3) \\
537(24.4) \\
1090(49.5) \\
261(11.8)\end{array}$ & $\begin{array}{l}552(24.9) \\
526(23.7) \\
802(36.2) \\
337(15.2)\end{array}$ & $\begin{array}{l}186(10.8) \\
400(23.3) \\
877(51.1) \\
253(14.8)\end{array}$ & $\begin{array}{l}402(23.1) \\
426(24.4) \\
720(41.3) \\
196(11.2)\end{array}$ & $\begin{array}{l}270(17.6) \\
358(23.3) \\
677(44.1) \\
230(15.0)\end{array}$ & 0.001 \\
\hline $\begin{array}{l}\text { Ever heard of STI, n (\%) } \\
\text { Yes } \\
\text { No }\end{array}$ & $\begin{array}{c}2026(91.6) \\
186(8.4) \\
\end{array}$ & $\begin{array}{l}1908(85.5) \\
324(15.5) \\
\end{array}$ & $\begin{array}{c}1587(92.2) \\
134(7.8) \\
\end{array}$ & $\begin{array}{l}1481(84.4) \\
274(15.6) \\
\end{array}$ & $\begin{array}{c}1448(94.1) \\
91(5.9) \\
\end{array}$ & 0.001 \\
\hline
\end{tabular}

RTI, reproductive tract infections; SD, standard deviation; IQR, interquartile range; STI, sexually transmitted infection. *P value for univarate analysis within the 2011 Nepal Demographic and Health Survey. 
middle reproductive years were more likely to be associated with reported RTI symptoms ( 15 to 25 years, $11.3 \%$; $>25$ to 35 years, $14.0 \%$; $>35$ years, $12.2 \%$; $\mathrm{P}=0.02$; Table 1$)$. The women who reported RTI symptoms were more likely to reside in a rural area if their husbands were currently migrating for work (rural residence with migrant husband $91.7 \%$, and non-migrant husband $84.2 \% \mathrm{P}=0.001)$. Women who reported RTI symptoms and whose husbands were currently migrating for work were more likely to reside in the Terai ecological zone than women who reported RTI symptoms and whose husbands were not migrating for work (Terai ecological zone: migrant husband $57.3 \%$, non-migrant husband $45.4 \% \mathrm{P}=0.008$ ). Residence in the DR was significantly associated with a husband's migration status (husband's migration status: Eastern 32.4\%, Central 26.9\%, Western 39.7\%, Mid-Western $29.6 \%$, Far Western 34.6\%, $\mathrm{P}=0.001$ ) (Table 2).

Multivariate logistic regression models investigated the association between the husband's migration status and reporting RTI symptoms by DR. We found that women whose husbands were migrating for $\geq 1$ year were more likely to report RTI symptoms than women whose husbands were not currently migrating for work if they lived in the Mid-West region (OR 1.93 95\%CI 1.023.67 ) or if they lived in Nepal's Far-West region (OR 2.89 95\% CI 1.24-6.73; Table 3). The prevalence of male migrant workers' wives reporting RTI symptoms was less than $10 \%$ in two NDHS sub-zones (RTI symptoms: Central Terai $9.4 \%$ and Far Western Terai 9.0\%; Figure 1).

Married women whose husbands were currently migrating for work were more likely to report RTI symptoms than married women whose husbands were not currently migrating for work in 7 of the 13 NDHS Sub-regions (Central Mountain, Far Western Hill, Eastern Terai, Central Terai, Western Terai, Mid Western Terai, and Far Western Terai). Married women whose husbands were not migrating for work were more likely to report RTI symptoms than married women whose husbands were currently migrating for work in 6 of the 13 NDHS Sub-regions (Eastern Mountain, Far/Mid/Western Mountain, Eastern Hill, Central Hill, Western Hill, and Mid Western Hill). Married women from the Central mountain Sub-region reported the highest percentage of RTI symptoms regardless of whether their husbands were migrating or not (Central mountain: migrant husband 21.9\%; non-migrant husband $17.3 \%$ ) (Figure 2).

\section{Discussion}

Among the $32.0 \%$ subset of women in our study who reported that their husbands were currently migrating for work, $12.6 \%$

Table 3. Multivariate logistic regression models determining the odds of reporting reproductive tract infections symptoms stratified by a husband's time away from home.

\begin{tabular}{lcc} 
Development region & Mligrating $\leq 1$ year* & Migrating > year* \\
Eastern & $1.49(0.93-2.39)$ & $1.03(0.57-1.86)$ \\
Central & $1.06(0.66-1.72)$ & $1.17(0.66-2.08)$ \\
\hline Western & $1.08(0.69-1.70)$ & $1.40(0.80-2.46)$ \\
Mid-Western & $1.09(0.75-1.58)$ & $1.93(1.02-3.67)$ \\
\hline Far-Western & $0.95(0.47-1.91)$ & $2.89(1.24-6.73)$ \\
\hline
\end{tabular}

Data based on the 2011 Nepal Demographic and Health Survey (NDHS) and adjusted for: wealth index, contraception use, age at first marriage, urban/rural, husband's education. *Reference category not currently migrating for work.

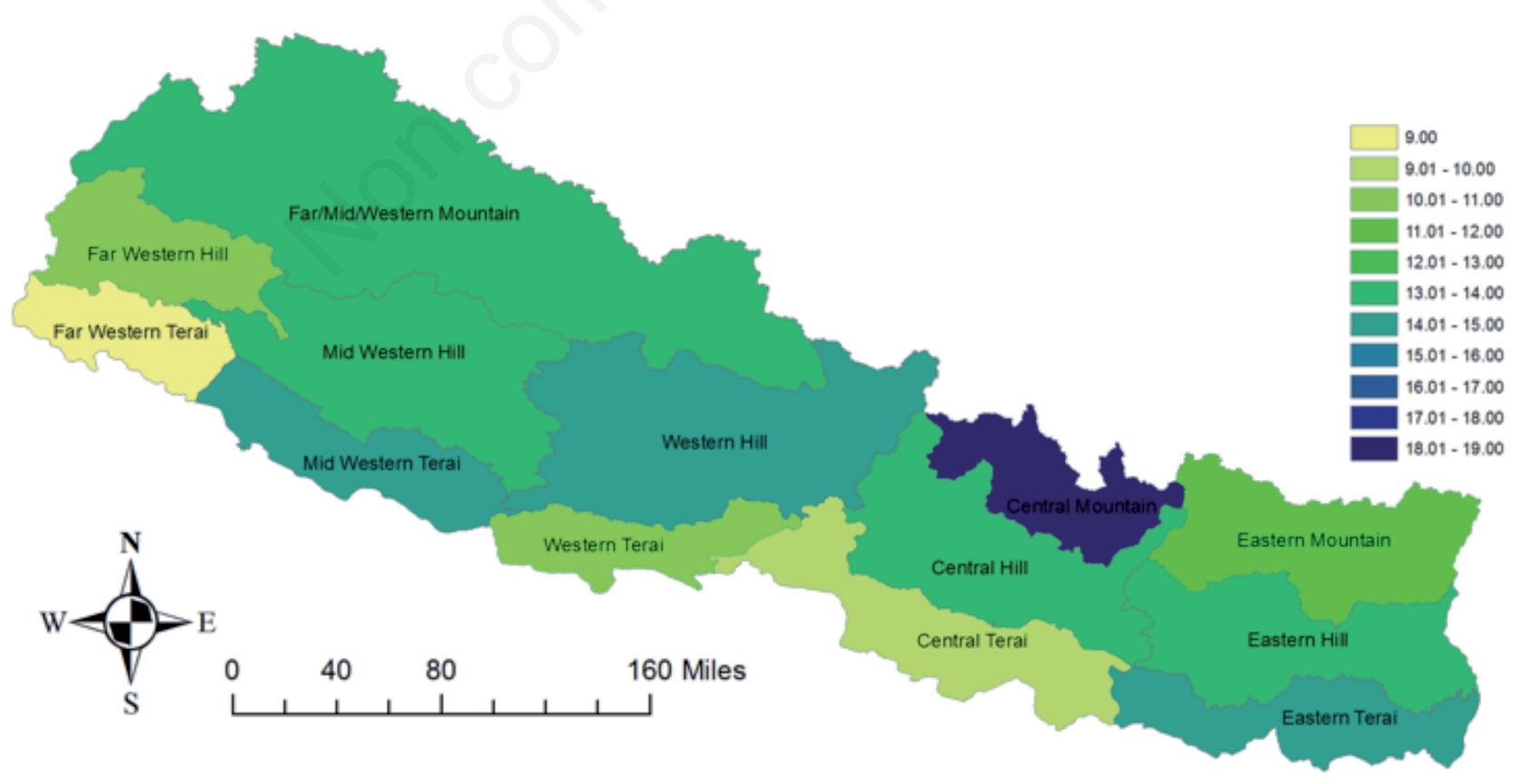

Figure 1. Percentage of married women in Nepal reporting reproductive tract infections symptoms according to the 2011 Nepal Demographic and Health Survey. 
reported RTI symptoms. Multivariate logistic regression models indicated increased the odds of a woman reporting RTI symptoms if she resided in the Mid-Western or Far-Western DRs and her husband was currently engaged in migrant labour for more than one year. Our results suggest that the sub-region where a woman lives in conjunction with her husband's migratory status is associated with her risk of having RTI symptoms. However, the migration association was not robust and the overall finding did not suggest an association between male migration and RTI symptoms in his wife. RTI rates in other South Asian countries are known to vary by geographical region (Begum et al., 2003; Rehan et al., 2009; Yasmin and Mukherjee, 2012). For example, the prevalence of RTIs in women varies by region in India, where the rates of RTIs for Uttar Pradesh, West Bengal, and Ludhiana are 34, 23.6, and $17.3 \%$, respectively (Nandan et al., 2001; Yasmin and Mukherjee, 2012; Philip et al., 2013). An eighteen months long study conducted in Pakistan's Punjab Province found that rural women were $32 \%$ more likely to have a STI identified through syndromic management compared to women living in urban areas (Khan et al., 2014). The likelihood of women reporting RTIs also differs by urban/rural status in Bangladesh (Bogaerts et al., 2001; Hawkes et al., 2002).

While there is sparse information on RTIs in relation to migration in Nepal, regions with high levels of STI risk factors are often the same regions characterised by high levels of migration. Nepal's Eastern and Central DRs have the largest percentage of migrant workers and some of the strongest indicators of STIs in Nepal (MOHP, 2012). The 2011 NDHS report suggest that men from Central DR reported a higher percentage of sex worker usage than the national average. Women from the Central DR were the least likely to know where to obtain a condom, while women from the Eastern DR were the least likely to report condom usage when hav- ing sex (MOHP, 2012). While in the overall univariate analysis, women without husbands away reported more RTIs, the prevalence differed by development regions and ecological zones. If both labour migration and STI rates are known to be associated with geospatial variables, then it is possible that RTI rates among the wives of migrant workers could correlate with these variables as well. Of note, certain geographical regions only had few husbands migrating, so the analyses could not be conducted.

Results from our study indicate that women whose husbands are currently migrating for $>1$ year and who reside in either the Mid-Western or Far-Western DR are more than twice as likely to report RTI symptoms than women whose husbands have never migrated for work, even after adjusting for wealth, contraception use, age at first marriage, urban/rural status, and the level of husband's education. Our results suggest that if a woman's husband is currently engaged in migrant work, her regional residence influences the likelihood of her reporting RTI symptoms. More studies are needed to assess whether some of these disparities are due to either women themselves or their husbands, in certain geographical regions, are having extramarital affairs that are the cause of infection. Previous reports indicate that most male Nepali migrant workers residing in the Mid-Western and Far-Western DR migrate to large Indian cities, such as Mumbai or New Delhi (Poudel et al., 2004) where HIV prevalence among sex workers is high and where Nepali migrant workers often engage with commercial sex workers (Poudel et al., 2003, 2004). Infectious diseases contracted by male migrant workers who migrated to India may be transmitted to their wives when they return, notably in Mid-Western or FarWestern Nepal.

The DRs with high rates of migrant activity and RTI symptoms could represent entry points of STIs into Nepal. Previous studies have reported that, although the percentage of individuals infected

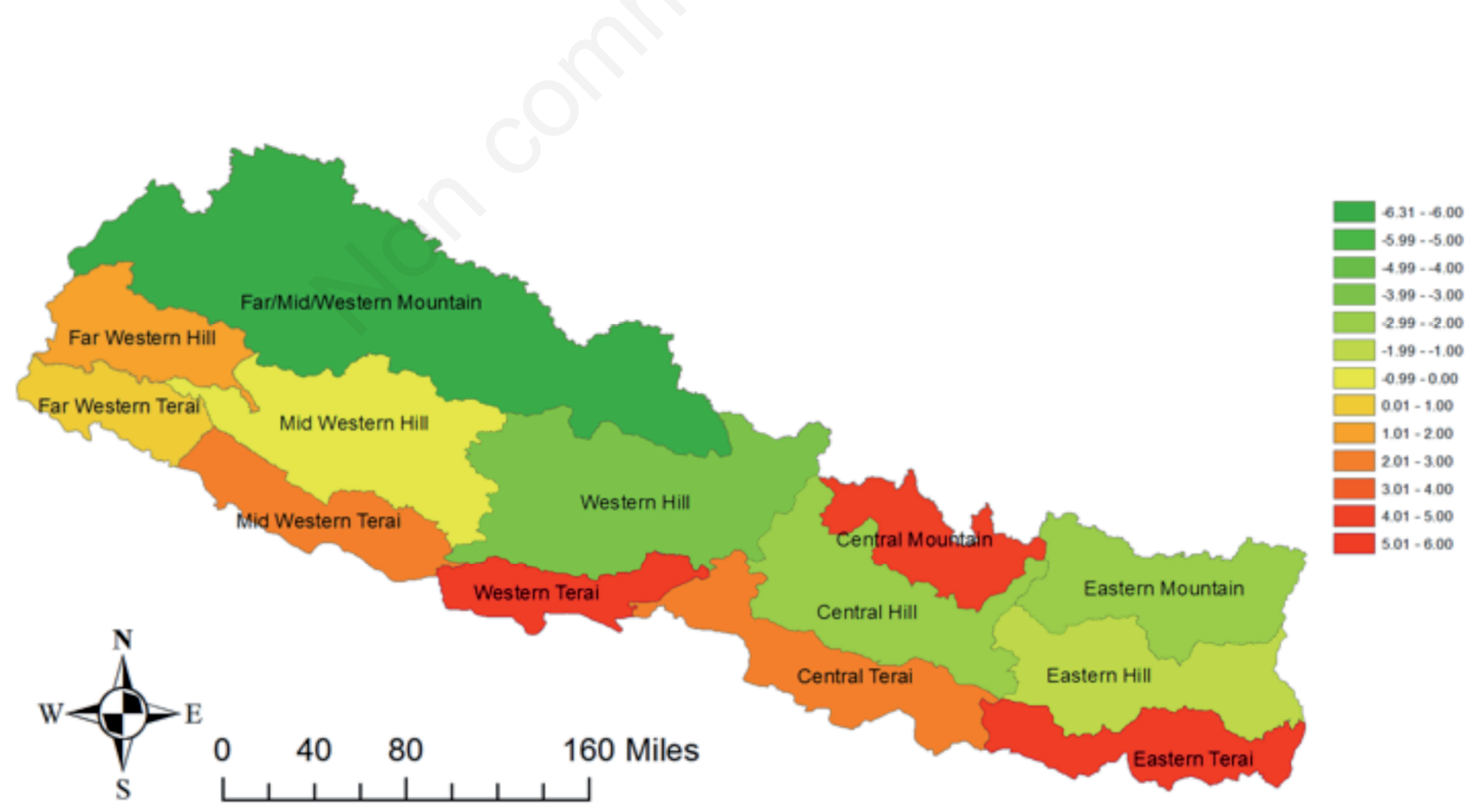

Figure 2. Difference in the percentage of women reporting reproductive tract infections symptoms with husbands living at home and with husbands currently migrating for work according to the 2011 Nepal Demographic and Health Survey. 
with HIV in Nepal is $<1 \%$ of the population (Government of Nepal, 2014), $>40 \%$ of individuals who test positive for HIV have engaged in migratory work (Poudel et al., 2003). One study determined that $22 \%$ of migrant workers returning to the Far West Doti District tested positive for syphilis (Thapa et al., 2014). Our study is compatible with these other studies suggesting that migratory work is a potential mode of entry for STIs into Nepal. Nepali truck stops and highway areas are well known for high STI rates (USAID and FHI Report, 2011), suggesting that the trucker-sex worker risk axis is relevant for Nepal as is true in many other nations. Migratory work represents a potential way in which new STI infections are entering Nepal. Though the overall rates of STIs in migrant workers were similar to the rates in non-migrant workers, the reference to the geographic region suggest complex dynamics within the migrant population.

Study strengths included the nationwide representativeness of the 2011 NDHS and the reasonable sample size. Study limitations included the ecological study design and our inability to translate group characteristics to the individual level. For example, only current migration is captured in the study and not the previous history of migration of the husbands or the women themselves are accounted for. Our outcome relies on self-reporting of RTI symptoms; syndromic identification of STIs and RTIs is known to have low sensitivity (Yin et al., 2008), though WHO considers syndromic identification of STIs and RTIs to be acceptable for screening in South Asia (WHO, 2011).

\section{Conclusions}

Our study suggests possible regional differences in RTI symptoms reported by married women in the NDHS. It is possible that a husband's migratory work is associated with the rates of RTI symptoms reported by married women in specific regions of Nepal. Additional studies providing laboratory-based survey data are needed to assess the role of labour migration on the rates of RTI symptoms in Nepal more definitively, to assess migration patterns over time in general, and to evaluate regional behavioural patterns and other factors associated with RTIs and STIs.

\section{References}

Asian Development Bank, 2016. Macroeconomic update Nepal. Asian Development Bank, Mandaluyong, Philippines.

Bam K, Thapa R, Newman MS, Bhatt LP, Bhatta SK, 2013. Sexual behavior and condom use among seasonal Dalit migrant laborers to India from Far West, Nepal: a qualitative study. PLoS One 8:e74903.

Begum A, Nilufar S, Akther K, Rahman A, Khatun F, Rahman M, 2003. Prevalence of selected reproductive tract infections among pregnant women attending an urban maternal and childcare unit in Dhaka, Bangladesh. J Health Popul Nutr 21:112-6.

Bogaerts J, Ahmed J, Akhter N, Begum N, Rahman M, Nahar S, Van Ranst M, Verhaegen J, 2001. Sexually transmitted infections among married women in Dhaka, Bangladesh: unexpected high prevalence of herpes simplex type 2 infection. Sex Transm Infect 77:114-9.

Bohara MS, Joshi AB, Lekhak B, Gurung G, 2012. Reproductive tract infections among women attending gynaecology outpa- tient department. Int J Infect Microbiol 1:29-33.

Burgert C, Colston J, Roy T, Zachary B, 2013. Geographic displacement procedure and georeferenced data release policy for the Demographic and Health Surveys. ICF International, Calverton, MD, USA.

Central Bureau of Statistics, 2012a. National population and housing census 2011. National Planning Commission Secretariat, Central Bureau of Statistics, Kathmandu, Nepal.

Central Bureau of Statistics, 2012b. Nepal multiple indicator cluster survey 2010, Mid-and Far-Western Regions, Final Report. Central Bureau of Statistics, Kathmandu, Nepal.

Government of Nepal, 2014. Labour migration for employment. A status report for Nepal: 2013/2014. Ministry of Labour and Employment, Kathmandu, Nepal.

Hawkes S, Morison L, Chakraborty J, Gausia K, Ahmed F, Islam SS, Alam N, Brown D, Mabey D, 2002. Reproductive tract infections: prevalence and risk factors in rural Bangladesh. B World Health Organ 80:180-8.

Hernandez LS, Winch PJ, Parker K, Gilman RH, 2006. Understandings of reproductive tract infections in a peri-urban pueblo joven in Lima, Peru. BMC Womens Health 6:7.

Johnson D, Chamot E, Lhaki P, Broker TR, Steben M, Steben M, Shrestha S, 2013. Prevalence and correlates of cervico-vaginal clinical syndromes among women attending a health camp in Lalitpur district of Nepal. Kathmandu Univ Med J 11:268-73.

Khan MA, Javed W, Ahmed M, Walley J, Munir MA, 2014. Sexually transmitted disease syndromic case management through public sector facilities: development and assessment study in Punjab Pakistan. Ann Glob Health 80:486-92.

Khanal M, Shrestha D, Panta P, Mehata S, 2013. Impact of male migration on contraceptive use, unmet need and fertility in Nepal. Further analysis of the 2011 Nepal Demographic and Health Survey. ICF International, Calverton, MD, USA.

Khatiwada N, Silwal P, Bhadra R, Tamang TM, 2013. Sexual and reproductive health of adolescents and youth in Nepal: trends and determinants: further analysis of the 2011 Nepal Demographic and Health Survey. ICF International, Calverton, MD, USA.

Kim le AT, Pham LT, Vu LH, Schelling E, 2012. Health services for reproductive tract infections among female migrant workers in industrial zones in Ha Noi, Viet Nam: an in-depth assessment. Reprod Health 9:4.

Ministry of Health and Population, 2012. New ERA and ICF International, 2012. Nepal Demographic and Health Survey 2011. Nepal Ministry of Health and Population and ICF International, Kathmandu, Nepal and Calverton, MD, USA.

Nandan D, Gupta YP, Krishnan V, Sharma A, Misra SK, 2001. Reproductive tract infection in women of reproductive age group in Sitapur/Shahjahanpur District of Uttar Pradesh. Indian J Public Health 45:8-13.

Nguyen HN, Hardesty M, Hong KT, 2011. In full swing? How do pendulum migrant labourers in Vietnam adjust their sexual perspectives to their rural-urban lives? Cult Health Sex 13:1193206

Philip PS, Benjamin AI, Sengupta P, 2013. Prevalence of symptoms suggestive of reproductive tract infections/sexually transmitted infections in women in an urban area of Ludhiana. Indian J Sex Transm Dis 34:83-8.

Poudel KC, Jimba M, Okumura J, Joshi AB, Wakai S, 2004. Migrants' risky sexual behaviours in India and at home in far western Nepal. Trop Med Int Health 9:897-903. 
Poudel KC, Okumura J, Sherchand JB, Jimba M, Murakami I, Wakai S, 2003. Mumbai disease in far western Nepal: HIV infection and syphilis among male migrant-returnees and nonmigrants. Trop Med Int Health 8:933-9.

Rehan N, Bokhari A, Nizamani NM, Jackson D, Naqvi HR, Qayyum K, Mansoor S, Muzaffar R, 2009. National study of reproductive tract infections among high risk groups of Lahore and Karachi. J Coll Physicians Surg Pak 19:228-31.

Thapa S, Bista N, Timilsina S, Buntinx F, Mathei C, 2014. Social and behavioural risk factors for HIV infection among the wives of labour migrants in Nepal. Int J Std AIDS 25:793-9.

Tuladhar H, 2005. An overview of reproductive health of women in Bajhang district. Nepal Med Coll J 7:107-11.

USAID, 2006. Guide to DHS statistics. Demographic and health surveys methodology. USAID, Washington, DC, USA.

USAID, 2012. Sampling and household listing manual. Demographic and health survey methodology. USAID, Washington, DC, USA.

USAID and FHI Report, 2011. Integrated Biological and Behavioral Surveillance Survey (IBBS) among truckers in 22
Terai highway districts of Nepal. USAID, Washington, DC, USA.

WHO, 2005. Sexually transmitted and other reproductive tract infections. World Health Organization, Geneva, Switzerland.

WHO, 2011. Management of sexually transmitted infections, regional guidelines. World Health Organization, Geneva, Switzerland.

Yasmin S, Mukherjee A, 2012. A cyto-epidemiological study on married women in reproductive age group (15-49 years) regarding reproductive tract infection in a rural community of West Bengal. Indian J Public Health 56:204-9.

Yin YP, Wu Z, Lin C, Guan J, Wen Y, Li L, Detels R, RotheramBorus MJ, Group NCHSPT, 2008. Syndromic and laboratory diagnosis of sexually transmitted infection: a comparative study in China. Int J Std AIDS 19:381-4.

Zuma K, Lurie MN, Williams BG, Mkaya-Mwamburi D, Garnett GP, Sturm AW, 2005. Risk factors of sexually transmitted infections among migrant and non-migrant sexual partnerships from rural South Africa. Epidemiol Infect 133:421-8. 